\title{
Maritime Econometrics: Models of Dry Cargo Ships and Tankers, 1996-2005 Survey
}

\author{
Alexandros M. Goulielmos ${ }^{1,2}$ \\ ${ }^{1}$ Department of Maritime Studies, University of Piraeus, Piraeus, Greece \\ ${ }^{2}$ Business College of Athens, Athens, Greece \\ Email: ag@unipi.gr,am.goulielmos@hotmail.com, agoulielmos@bca.edu.gr
}

How to cite this paper: Goulielmos, A.M. (2018) Maritime Econometrics: Models of Dry Cargo Ships and Tankers, 1996-2005 Surve. Modern Economy, 9, 2196-2223. https://doi.org/10.4236/me.2018.912136

Received: November 6, 2018

Accepted: December 16, 2018

Published: December 19, 2018

Copyright $\odot 2018$ by author and Scientific Research Publishing Inc. This work is licensed under the Creative Commons Attribution International License (CC BY 4.0).

http://creativecommons.org/licenses/by/4.0/ Open Access

\begin{abstract}
We reviewed the most representative papers belonging to "maritime econometrics" published between 1996 and 2005: a scientific branch in-the-making, we believe. The papers covered the econometrics of the dry-cargo and liquid-cargo ships. We also mentioned a number of papers selected from a paper of Prof. Button in 2005. We traced the progress of "general econometrics" (since the "ARCH model" in 1982) in connection with its application to Maritime Markets (1996). We saw that the progress was made through doctoral theses of maritime economists (since 1996), who applied general econometrics to shipping markets. We also traced the evolution of this applied branch of economics from 1967 to 2005. Maritime economists during this period committed certain mistakes: 1) they relied on "spurious regressions"; 2) they did not apply any tests for stationarity, and 3) they took "co-integration" as a sufficient condition for Random Walk-RW. However, they-unfairly, we believe-have been criticized (by Button) for: 1) using only short run models or, even worse, sticking to Marshall's "market period"; 2) ignoring "institutional economics"; 3) copying their models from others, producing nothing new and original... They were also criticized for using almost exclusively GARCH model, and for being deceived in their conclusions by data, because longer data in calendar time supports RW, and data in days, weeks reject the existence of random walk, even belonging to same period and market...
\end{abstract}

\section{Keywords}

A Survey of Maritime Econometric Models: 1996-2005, Statistical Errors Committed by Maritime Economists, Random Walk, Mention of "Maritime Economics"-Papers since 1967-A Selected List 


\section{Introduction}

This decade, 1996-2005, was dominated by papers coming mostly from-let us say-“English School"-a personal classification. In other words, they were products of research carried-out by people of the City of London ${ }^{1}$ University and the University at Guildhall. There are additional, but not massive, contributions from other universities, no doubt, e.g. "Cardiff University" and "Norwegian School". Pioneering papers came also from the other side of the Atlantic, i.e. USA, by Li and Parsons and by Berg-Andreassen.

This paper aims at underlying certain mistakes that maritime econometricians committed, for future avoidance, and mainly to show the progress of quantitative maritime economics made during this decade (1996-2005). Many dilemmas are this way revealed. It is also shown that maritime economists are still not clear, if e.g. RW prevails, or not, in maritime markets, as this is showed by the co-integration ${ }^{2}$ tests. Moreover, a selected list out of about 100 maritime economic papers is presented due to Button, showing the evolution of this science since 1967.

The paper is organized in 4 parts: Part I surveys the models, which appeared between 1996 and 2000, when indeed a high production achieved. Part II covers the papers, which appeared from 2001 to 2005. Part III gives a list of these papers together with additional information about them. Part IV presents briefly parts of the tentatively useful-though unfair for maritime economists-paper of Prof. Button [1], where he criticized maritime economists. Finally, we proceeded to concluding remarks.

\section{Maritime Econometric Models, 1996-2000}

\subsection{Non-Autoregressive Maritime Models, 1996}

Kavussanos [2], after his $1992 \mathrm{PhD}$, and using UN data for dry bulk, (wished, we believe, to continue the initiative of Eriksen ${ }^{3}$ (in 1977)), constructed a model to explain "bilateral seaborne trade flows", i.e. demand. He used the "neoclassical optimization" plus an "objective "CRESH"-type function": $y=\mu\left(m_{i}, \cdots, m_{j}\right)$, (1), where $\mathrm{m}$ stands for $j$ imports of g goods $k=1, \cdots g$, from $\mathrm{n}$ trade partners $i=1, \cdots, n$. (1) was optimized. He also assumed a constant ratio of elasticities of substitution, and an "homogeneous-homothetic function" of "multi-stage budgeting" (of 1971).

Chang and Chang [3] found ${ }^{4}$ that the (ill-fated ${ }^{5}$ ) BIFFEX ${ }^{6}$ was not widely used as hedging tool, because it could not predict physical market. They tested the ${ }^{1}$ Much helped the system-for the production of papers-adopted by the City University to "attach" $\sim 3$ doctoral candidates to each professor.

${ }^{2} \mathrm{~A}$ method, which defines the long run relationship among a group of time series variables.

${ }^{3}$ Eriksen first tried to model "maritime demand": Eriksen, I.E. (1977). The demand for bulk ship services, Norwegian Maritime Research, 2, 22-26.

${ }^{4} \mathrm{~A}$ “spurious regression".

${ }^{5}$ Abandoned.

"Baltic international freight futures exchange" (1985). Cullinane K.P.B. submitted a doctoral thesis in the Polytechnic of South West in 1989 on BIFFEX. Greek shipowners did not use BIFFEX. 
predictability of BIFFEX (1985-1993), which found intact for 6 months ahead, but not for shorter periods (i.e. from 1 month to 6 months), using a linear regression: $Y=a+b X t \quad$ (2). Also, $\mathrm{T}$ stood for expiring time, BFI (Baltic Freight Index) for the dependent variable, "BIFFEX price" for the independent variable and $t$ for "now"; a time series analysis used. OLS applied on 24 data sets. The 1-month lag gave a high $R^{2}$ of 0.89 . All 24 regressions, however, showed autocorrelation, cured by using the "Durbin"s two-step 1976 estimators". They concluded that "BIFFEX prices" can predict movements of the dry bulk shipping market, up to 6 months maximum prior to a real happening in the physical market, with accuracy from $90 \%$ for 1 -month lag and $23 \%$ for a 6 -month lag. The time which elapses distorts predictions.

Grammenos and Marcoulis [4]) examined whether the "return performance" of 19 companies related to company's beta $^{7}=\beta$, or to: 1 ) stock exchange price, 2 ) leverage, 3) average fleet age and 4) level of dividends (1989-1993). They used OLS, and a cross-section regression (due to Fama and MacBeth in 1973). They found that leverage and average age are better indicators than betas- $\beta$. Shipping betas found $<1$ and lowest in NYSE...

\subsection{The ARCH: A Non-Linear Stochastic Process (1982)-Co-Integration, VAR and SEM}

Maritime economists, in 1996, used certain models to exhibit the phenomenon of the "autoregressive conditional hetero-skedasticity"-ARCH [5]. ARCH's frequency distribution is "high-peaked" and "fat-tailed", and empirical applications show that financial time series ${ }^{8}$ exhibit a statistically significant ARCH [6]. Worth noting is that maritime time series resembles financial one.

Engle [5] argued that time series follow a normal distribution, but variance can be time-dependent. In other words, "expected variance" is conditional on its past, though assumed stable (time-varying). The $\mathrm{ARCH}$ is: $C t=S t * e t$ (3), where $\mathrm{Ct}$ is the change in observed values at time $\mathrm{t}$, St is standard deviation and et is a "standard normal random variable"; $S^{2} t=f o+f * e^{2} t-1$ (4), where $\mathrm{f}$ is a constant. ARCH is a "short-memory" process with short-term randomness and long-term anti-persistence.

Worth noting is that there are variables, which can be examined separately, but their trends, (in the long-run), are common. In other words, 2 or more "non-stationary" variables, having the same degree of "co-integration", let us say $\mathrm{d}$, are integrated. This happens if their linear combination, or a vector of them, is integrated at a degree $b($ where $b<d$ ). The information about the existence of $a$ common trend of the variables is obtained through the "error correction" mechanism.

"Co-integration" theory is due to Granger [7] [8] and Engle and Granger [9], ${ }^{7}$ The amount by which the stock reacts to market $=\beta$.

${ }^{8}$ The model addressed the phenomenon of "volatility cluster", where large and small forecast errors occur in clusters. 
and it is closely related to the "Error Correction" model-ECM9. A co-integrated system is represented by $\mathrm{VAR}^{10}$ (Vector auto-regression). VAR indeed provided a powerful link to "long-run equilibrium-based"-economic theories. Granger [7] [8], first formalized co-integration theory. Engle and Granger [9] supplemented it with a "single-equation estimation procedure". Johansen [10] provided the "simultaneous-equation"-SEM-estimation. Co-integration theory helped "time-series" econometrics, and advanced greatly by the empirical success of ECM; the EC term was frequently made up of "co-integrated non-stationary" variables.

\subsection{The GARCH Model in 1986}

This is a generalized ARCH, due to Bollerslev [11], where Equation (4) above becomes: $S^{2} t=f o+f * e^{2} t-1+g * S^{2} t-1 \quad$ (5) [12]. It was accepted by then that volatility clusters due to dependence ${ }^{11}$, but GARCH can model this. It starts with a conventional "Brownian model" of changes in prices, and when volatility jumps, the model sets-in a new parameter to make normal distribution curve grow, and vice versa. In other words, normal distribution vibrates to fit to reality... But, an important unanswered so far question is: "why normal distribution vibrates"...?

Nevertheless, GARCH is the flagship of econometrics since 1986 with a number of variations/improvements. In fact, GARCH is a shorthand name for: a "generalized", "auto-regressive", "conditional" "hetero-skedastic" model. Really is a set of statistical tools to model data, whose variability changes with time; this is why it is called "hetero-skedastic". The "auto-regressive" "conditional" stands for changes in variability controlled by data's own past behavior.

In other words, ARCH model [5] generalized to accommodate more situations, and become GARCH [11]. This is not "self-similar ${ }^{12 " ~[6] . ~ I t ~ b e c a m e ~ v e r y ~}$ popular also among maritime economists, as it allows for "fat tails" and "high peaked" distributions, characteristics of maritime time series, with alpha $=1.50$. GARCH, however, has marginally persistent values. ARCH and GARCH in no way fit in the "Fractal ${ }^{13}$ Market Hypothesis"-FEMH, with the exception of "fractal ARIMA" and "IGARCH"14 (i.e. integrated variance-GARCH) [13].

\footnotetext{
${ }^{9} \mathrm{~A}$ dynamic model, where the change of a variable in $\mathrm{t}$ is related to the distance between its value in the previous period and its value in a long-run equilibrium. It is used to estimate short-run dynamic relationships between co-integrated variables and their rate of adjustment to the long-run equilibrium relationship... The variables used are stationary, $1^{\text {st }}$ differenced, plus a term which captures movements back, towards long run equilibrium.

${ }^{10}$ This is a generalization of the "error correction model" to a system of equations describing multivariate non-stationary time series.

${ }^{11}$ This means that individual observations may not be independent or one must test for independence or for IID.

${ }^{12} \mathrm{~A}$ model of a part is similar with its all, under different scale. This is like the relationship of a branch to its tree.

${ }^{13}$ Mathematics using non-integer numbers (or fractals). The word "fractal" comes from the Latin verb "frangere", which means to "break". The Geometry of Nature is fractal. Euclid used only integers in his geometry.

${ }^{14}$ These are models with $\infty$ unconditional variance.
} 
A regression now of two variables: $Y t-b X t+e t$ (7), where et is "integrated" of order 0 , is "stationary" if $Y t$ and $X t$ are integrated by the same degree. Co-integration appeared mainly in 1986 and in 1987 in Econometrica; Johan$\operatorname{sen}^{15}$ [10] proposed thereafter the VAR model, considering that the previous "Granger-Engle" method had serious shortcomings... Econometrics ${ }^{16}$ thus is a young science in adaptation being always in-the-making.

Certain maritime models that appeared before 1996, "assumed" maritime time series to be stationary, without a test... A stochastic evolution $Y t$ is stationary, if its mean and variance are stable, and independent of $t$, and covariance is a function of $\mathrm{t}-\mathrm{s}$, but not of $\mathrm{t}$ or s. Also for $\operatorname{AR}(p)$, the

$C(z)=1-\rho_{1} z-\rho_{2} z^{2}-\cdots-\rho p z^{p}=0 \quad(8)$, and it must have all characteristic roots greater than $|1|$.

\subsection{Further Maritime Economic Models, 1996-2000}

Kavussanos [14] studied the "price-risk" of tanker vessels of different sizes, using $\mathrm{ARCH}$ and GARCH to analyze the "time-varying" behavior of freight rates. Also, he analyzed dry bulks of different sizes, and their spots and time charters (freight rates). He found advantages in using ARCH and GARCH models, especially if one "compresses" the 2 alternative approaches of the freight rate market, i.e., the "classical linear" and "GARCH".

Kavussanos [15] estimated the "conditional volatilities" of monthly freight rates (spots; time charters) in the dry cargo market (1973-1992), using a "reduced form" due to Beenstock and Vergottis [16]. The TC (time charter) corresponded to an aggregate index for Cape, Panamax and Handy ships. The lag of all data series was integrated of order: $1(=\mathrm{RW})$.

Berg-Andreassen [17] examined BFI (1985-1988) over 10 selected routes, using quarterly observations (1980-1989), and the $2^{\text {nd }}$ hand prices of dry bulks, using equation $X i=\rho X i-1+e i(i=1, \cdots, t)$ (6), where $\rho$ is a constant, $e i=$ an independent random variable, and $\rho<1$ (=no mean). He used co-integration theory [18] for $2^{\text {nd }}$ hand prices and freight rates for 3 routes.

He applied the tests of "Dickey-Fuller-DF" [19], and of "ADF" Augmented DF [20], on 10 BIFFEX freight rate series (1004 days), being the standard tests for RW. Also, he applied the tests due to MacKinnon [21], and Engle and Granger [9]. Worth noting is that the above methods, using $1^{\text {st }}$ differences, or a trend elimination, are misleading as far as "non-stationarity" is concerned.

He further reached contradictory conclusions arguing that the distributions of "freight rates" and of " 2 nd hand markets" belong to a "Pareto family", with "al-

${ }^{15}$ Engle \& Granger do not permit testing of hypotheses on co-integrating relationships (see Brooks, C. (2014), Introductory Econometrics for Finance, $3^{\text {rd }}$ edition, p. 389).

${ }^{16} \mathrm{~A}$ simple definition (ours) of econometrics is: "A science applying statistical methods to economic measures with a purpose to estimate-quantitatively-their impact". This science was born out of the fact that Social sciences had always the disadvantage of being unable to perform experiments, like Physics or Chemistry. This science made a great progress since 1969, when two econometricians won a Nobel for the so called "micro-econometrics" (in 2000: Heckman J. and McFadden D. from USA). A Nobel for econometrics awarded also in 1969, 1980, 1989, 1993 and 2003 (to Engle R.F. and Granger C.W.J.). 
pha ${ }^{17 \text { " }}$ ranging from 1.2 to 1.8 , which by strong evidence, follow RW...RW's alpha, however, needs to be equal to 2 , with zero skewness $(\beta=0) \ldots$ He also rejected all previous models, which used "OLS regression". He stressed that maritime economists ignored stationarity. Moreover, ADF test considered less powerful than DF. He concluded that according to ADF freight rates follow RW; the original process was non-stationary, but 1 st differences were, and integrated of order 1. Surprisingly, all series-except Gaussian-did not pass "normality test" ${ }^{18}$ at $1 \%$ level of significance, due to extreme leptokurtosis. As a result, we doubt his, (though mixed), conclusions.

More than $1 / 2$ of his paper, dealing with the "distributions and characteristic functions", missed $^{19}$ the opportunity to dispute the two universal truths in maritime economics: 1) that freight rates' changes are statistically "independent" and 2) that they are "normally distributed". His further criticism based on "spurious regression" that appeared in late 1980s, when variables of different order of integration included in the same regression model. This problem led thereafter to the "error correction model"-ECM, mentioned above.

Glen [24] modeled the relationship between the "level of gross investment in shipping" and the "relevant incentives for it". Data: 1963-1993 and 1963-1987. He criticized-rather unfairly-McWilliams et al. [25]—by using co-integration theory (1992-1993) — because some of their results considered wrong. He used also ECM, time series and OLS. He commented also on Marlow's work [26], where provoked late Prof. Goss R and Marlow R [27] to reply. A comment on this debate was also made by Gardner [28].

Veenstra and Franses [29] studied the (monthly) freight rates

(09/1983-08/1993) for 3 Cape and 3 Panamax routes, using ADF, (no time trend), on logarithmic observations. All series found non-stationary at $1 \%$ and $5 \%$ confidence level and for 2 Panamax routes, stationarity was also rejected. They found that the specification of these long-term relationships did not improve the accuracy of the short-term or long-term forecasts, due to corroborations of "EMH". They assumed that the logs of the freight rates are integrated of order 1, and thus follow RW [30].

Kavussanos [31] studied the volatility of $2^{\text {nd }}$ hand prices of dry-bulks. The volatilities assumed time-varying over different sizes. He used monthly observations (1976-1995). He reported that the $\log$ of $2^{\text {nd }}$ hand prices are integrated of order $1(=\mathrm{RW})$. Time charters found stationary; this is, however, a contradiction to his previous work [15]. Li and Parsons [32] were the 1st to use a non-linear regression in forecasting tanker freight rates, using "Artificial Neural Networks".

${ }^{17}$ An exponent measuring how wildly prices vary, or how "fat" the tails of the price-change curve are. An alpha of 1.7 indicates strong variation. An alpha $=1$ indicates a Cauchy distribution and a 2 normal distribution.

${ }^{18}$ Bera and Jarque [22] used a parametric test for normality with a Lagrange multiplier: NORM = $\left[n / 6 \mathrm{a}_{3}{ }^{2}+n / 24\left(a_{4}-3\right)^{2}\right]$, where $\mathrm{n}=$ the number of observations, $\mathrm{a}_{3}$ the skewness coefficient $(=0$; third moment) and a 4 kurtosis coefficient (fourth moment $=3$ ), using $\chi^{2}$ distribution with 2 degrees of freedom.

${ }^{19}$ He mentioned Mandelbrot's 1963 paper, but Mandelbrot wrote (2006 with Hudson, p. 7, [23]) his 1963 and 1965 models of behavior, were incompatible, and reconciled later in 1972. 
Berg-Andreassen [33] modeled the relationship between spot and time charter rates for 3 markets and ship sizes, over 40 quarters (10 years; BFI = Baltic freight Index). Finally, the "conventional wisdom" model accepted. Residuals assumed normally distributed with constant standard deviation and zero mean. He argued that changes ${ }^{20}$ matter, not levels. eit = yit-aoi-alis sit (9), where last term shows $1^{\text {st }}$ order differences; the "normality test" accepted at $10 \%$ confidence level. He used co-integration, ADF, “Johansen 1988 likelihood ratio test" [10], and the "Koyck model".

He rejected Zannetos' in 1966, Koyck and rational expectations. He criticized also Beenstock and Vergottis' [34] [35] and Hale and Vanags' [36]. All freight rates found integrated of order 1 (=RW). He presented the co-integration tests, but without a further model, which, we reckon, required.

Glen [37] found that the (monthly) observations of tanker and dry cargo markets are co-integrated [10], and thus inefficient-unless the factors creating common trends are stochastic. In an ideal market of ship prices-following Fama [38] - ship prices fully reflect all relevant information, and thus a $2^{\text {nd }}$ hand ship market is a "fair" game, as price is "right" and general market prices are also "right". He modeled $2^{\text {nd }}$ hand ship markets (tankers and dry cargoes) as efficient, using data: 1979-1995 for dry cargo and 1979-1988 for tankers. He used a multivariate co-integration analysis, linear data and stationarity. The logs of the $2^{\text {nd }}$ hand prices found integrated of order $1(=\mathrm{RW})$ [39]. Asset prices are also co-integrated. His results on EMH, however, were mixed...

Glen and Rogers [40] argued that by examining the statistical properties of 19 dry cargo rate series (indices) for Cape, in all routes, they found extremely high correlations and non-stationarity, except for the $1^{\text {st }}$ differences. So, the presence of co-integration [10] and VCM showed that long-run stable relationships exist. The freight rates, in level form, found non-stationary. Using $1^{\text {st }}$ differences the "unit root" hypothesis rejected.

Kavussanos and Marcoulis [41] investigated the behavior of water transportation companies, (40 in 1994, 28 in 1995), stock returns in the US stock exchange (1985-Jan. 1994; 1984-1995) to discover whether systematic risk of the industry is different etc., in the context of $\mathrm{CAPM}^{21}$. They used co-integration and stationarity. The shortcomings of CAPM ${ }^{22}$ are by now well known. CAPM is based on normal distribution [23]. The average beta- $\beta^{23}$ of shipping companies found not different, though smaller, than market's $\beta$; shipping stocks were not underpriced; the non-systematic diversifiable risk rose; the size had an effect, (smaller

${ }^{20}$ In all our papers we used " 1 st logarithmic differences". These secured stationarity.

${ }^{21}$ Capital asset pricing model.

${ }^{22}$ This is a model of equilibrium in financial markets used to generate predictions about the structure of returns on assets. It wrongly assumes no transaction costs and no taxes. Moreover, all investors do not have one period investment horizons; they do not have the same expectations etc. and they do not use a risk-free interest.

${ }^{23}$ Finance provided a coefficient called beta- $\beta$-as mentioned, to enable stock investors to distinguish the volatility of a stock compared it with the volatility of the overall market. It is based on the principle: "the more you risk, the more you expect to gain" (Mandelbrot and Hudson, (2006), p. 68 and after [23]). 
companies had higher returns at higher risk; 1984-1989); “alpha” was also affected.

Kavussanos and Marcoulis [42] have also showed lower betas - $\beta$ for US water transport companies. These conclusions come as a surprise for us, as we all maritime economists have the strong feeling that shipping is number one industry in volatility, cyclicality, unpredictability and thus risk!

Tvedt [43] modeled the TCE (time charter equivalent) of spot rates for the VLCC (very large crude carrier) market, and found that freight rates follow a "geometric mean reversion" process. Uncertainty also related to rates, and accordingly, a VLCC valued. "Lay-up" and "scrapping" were the options to spot market. Demand, only to a very small extent, depended on freight rates, if freight rates are a small \% of the CIF price of oil. Supply in the short run was quite inelastic, if idle vessels did not exist. Low freight rates caused ship's lay-up (the shut-up situation for a vessel). Freight rates can be very high and trigger orders for new ships with an at least one year lag. This model bears the shortcomings of the "Brownian motion" and "CAPM", we reckon.

Glen and Martin [44] — copied Kavussanos [14] on tankers-by estimating the "mean freight rate" or "conditional mean", using data for levels, and examining-statistically-if there is a connection between "risk" and "size" (of tankers): 40,000 - 70,000 dwt (Curacao-New Orleans route); 70,000 - 150,000 (Med.-UK route) and 200,000 - 299,000 (Ras Tanura-Rotterdam route). Also, between "spot market" and "time charter". They used a reduced form due to Beenstock and Vergottis [16]. The freight rate was determined as a function of: an exogenous demand (proxy: industrial production); variable costs (proxy: bunker prices) and of existing supply capacity (stock (in dwt); where $\mathrm{K}=$ total tanker fleet).

We disagree with the selection of some of the above proxies, though we understand the difficulties to find appropriate data, e.g. for "shipping profits". Moreover, the "time charter rate" assumed wrongly as a function of the "expected future level of bunker prices". Markets assumed competitive.

They confirmed-statistically_that there are systematic differences in risk in investing in tankers of different sizes, and in spots vis-à-vis time charters, using GARCH (data: 1986-1995; monthly) and the "Maximum likelihood/full information method". Risk represented by standard deviation ${ }^{24}$, but divided ${ }^{25}$ by mean. Volatility, and thus risk $R$ is: $R=f\left(S,-C d^{*}\right) \quad(10)$ (*except 6 months in 1987-1988), where $S$ stands for size of the ship and $C d$ stands for charter duration.

All time series in above work, but one, found non-stationary in levels, and stationary in $1^{\text {st }}$ differences, except bunker prices. The models found consistent with the theoretical predictions of the "Beenstock-Vergottis' 1993 model" [16]. Worth noting is that time charter data in all routes showed a significant coefficient of the "Bera-Jarque test" [22] at 10\% confidence level, indicating "fat tails" and "leptokurtosis", invalidating, we reckon, diagnostic and estimation results

\footnotetext{
${ }^{24}$ Standard deviation as a risk yardstick is for some time now disputed.

${ }^{25}$ In rescaled range analysis, scale divided by standard deviation.
} 


\section{[23] [45].}

Kavussanos and Marcoulis [46] examined 14 water transportation companies' stock returns (1984-1995) in NYSE, using CAPM and a number of multi-equation regressions. They found that average betas $-\beta^{26}$ of shipping companies are 0.95 and 0.94 , i.e. lower than market's beta- $\beta$, among 7 other industries. They concluded that shipping is attractive providing higher returns. Kavussanos [47] confirmed by Kavussanos and Nomikos (2000).

Berg-Andreassen [48] outlined a "CAPM model" for owners to decide "chartering strategies" in bulk shipping. Strandenes [49] examined-in a simulation model $^{27}$ - the circumstances under which the tanker market might become a two-tier ${ }^{28}$ market with different freight rates due to "OPA 1990" (oil pollution act in USA in 1990). She saw two-tier freight rates in Dec. 1994 due to COFR ("certificates of financial responsibility").

Kavussanos and Nomikos [51] assured that BFI follows RW; they focused on the unbiasedness of BIFFEX future prices. Kavussanos and Nomikos [52] estimated the time-varying and constant hedge ratios in BIFFEX, using GARCH and GARCH-X. They found that the $2^{\text {nd }}$ model is better, when risks in spot market are falling. This is due to the heterogeneous composition of the BFI index, which led to its reconciliation with, and the introduction of, the BPI (Baltic Panamax index).

Veenstra [30] investigated empirically the relation between spot and period freight rates for dry bulk shipping, 1980-1993, (30 k, 55 k, and 120 k). He found evidence that the "present value" model provides a valid description. There is a term structure in freight rates. He used the methodology of Campbell and Shiller [53] and especially [54]. No clear statement can be made, however, for the efficiency of the voyage market. He applied ADF test in 1981 [20], Engle and Granger 1987 [9], the VAR, unit roots and the 1990 Johansen (co-integration theory) [18].

Summarizing, most of the above works fell in the area and in the period dominated by ARCH and GARCH models-though with a 14-year delay. Three models fell in OLS regression, and in other "non-autoregressive" models. Most, but not all, of the above models supported the existence of: $\mathrm{RW}^{29}$, EMH and Rational Expectations-RE. Some further progress has to be made here, we believe, to get clearer conclusions. If EMH holds, then asset prices, (and thus the prices of $2^{\text {nd }}$ hand ships), must rapidly reflect all relevant and available information. EMH and RE suggest that asset prices (or their natural logs) should follow a RW or RW + drift ${ }^{30}$. Do they? Goulielmos and Psifia, [55], however, "proved" that

\footnotetext{
${ }^{26}$ This is the amount by which a stock reacts to market. It is based on the assumption that "the more you risk, the more you expect to gain".

${ }^{27}$ She first applied simulation models to shipping.

${ }^{28}$ Tamvakis [50] found evidence of premiums to tankers trading to US ports, but these were not due to different "quality" of ship services.

${ }^{29} \mathrm{~A}$ model where the $\mathrm{t}$ value of a series is the previous value perturbed by a white noise (error) term:

(1) $Y t=m+Y t-1+U t$ or (2) $Y t=a+b t+U t$, where there is an intercept " $a$ ".

${ }^{30}$ Their differences cannot be predicted but only their long term average values.
} 
randomness was absent in "trip and time charter" freight rate indices in 1968-2003 (over 36 years).

\section{Maritime Modeling, 2000-2005}

Kavussanos and Alizadex [56], examined the seasonality pattern in dry bulk shipping, and especially among different vessel sizes, contracts' duration and market conditions, applying a "unit root" test. Dikos and Papapostolou [57], using Shiller [58] examined the volatility between 4 different sizes of tankers, 1980-1993, over 2 different freight rate markets (spot and time charters). Spots are more volatile $\left(^{*}\right)$ than time charters, except for Aframax. Larger vessels are more volatile $\left.{ }^{* *}\right)$ than smaller ones, except Aframax. From this, authors concluded that "period freight rates" appear to be perfect foresights of future "spot rates", which we doubt. Moreover, we may ask "why Aframax did not conform?" $\left.{ }^{*}\right)$ This is plausible. $\left.{ }^{(*}\right)$ This is doubtful.

Kavussanos and Alizadeh [59], investigated the validity of the EMH combined with "RE" in dry bulk ship prices, 1976-1997. They tested using "orthogonality"31 and the "unpredictability" of excess returns on investments, using VAR (due to Campbell and Shiller [54]) extended to a "variable VAR" [54].

This considered proper for real assets with limited economic life, like vessels. The prices of new-buildings and of $2^{\text {nd }}$ hand vessels are not determined efficiently (in 1970 Fama's sense; and also in 1991) due to "time-varying risk premiums". These were related to the excess returns to investors' perception of risk using GARCH-M (in the mean).

Looking at their forecasting (with a very narrowed-down $\mathrm{X}$ axis), we found differences between actual and theoretical price series, where at certain years reached a maximum difference from actual of $\$ \sim 5 \mathrm{~m}$ (in handy sizes), a fact making their model not entirely accurate.

Tvedt [60] examined the lack of stationarity in freight rates (using spots, 1984-1999, 748 observations; weekly TCE, 1988-1999, 591 observations), $2^{\text {nd }}$ hand (5-year old) and new-building prices (3 sizes; 1970-1999; 119 observations). He obtained contradictory results (Table 1$)$. He used "SeaWin database" and BFI (1995-1999, 3,722 days). The ship sizes were: handy (30,000); Cape (120 - $150 \mathrm{k}$ ) and Panamax (60 - $70 \mathrm{k}$ ). He applied ADF (no trend) [29]. He confirmed that freight rates and $2^{\text {nd }}$ hand prices are stationary and do not follow random walk.

He also used observations expressed in Japanese Yen. In Yen, the results of the de-trended freight rates, were clearer and their volatility lower, vis-à-vis $\$$. He argued that Tinbergen ${ }^{32}$ (in 1931, 1933 and 1934) assumed "dry bulk ship prices" to show a downward trend due to increased efficiency. They were, however, cyclical, or "mean reverting", due to the delayed capacity adjustment [61]. This means that an anti-persistent time series reverses itself more often than a random series; if the system was up in $\mathrm{t}-1$, it is more likely that it will be down in

\footnotetext{
${ }^{31}$ Two vectors are said to be orthogonal if their product is zero. This means zero correlation.

${ }^{32}$ Tinbergen, J. (1959). Selected papers edited by L H Klassen, North Holland, Amsterdam.
} 
Table 1. Main findings of Tvedt [60].

\begin{tabular}{llll}
\hline $\begin{array}{l}\text { Newbuilding prices in Yen: } \\
\rightarrow \text { RW accepted. }\end{array}$ & $\begin{array}{l}2^{\text {nd }} \text { hand prices in Yen: } \\
\rightarrow \text { RW accepted. }\end{array}$ & $\begin{array}{l}\text { Freight rates in Yen: } \\
\rightarrow \text { stationary } \rightarrow \mathrm{RW} \text { rejected. }\end{array}$ & $\begin{array}{l}\text { BFI in Yen: } \rightarrow \mathrm{RW} \text { rejected at } 5 \% \\
\text { confidence level. There is a Mean } \\
\text { reverting structure round a } \\
\text { downward sloping trend. }\end{array}$ \\
$\begin{array}{l}\text { Exception: Cape and Panamax, } \\
\text { at } 10 \% \text { confidence level. }\end{array}$ & $\begin{array}{l}\text { Exception: spots in coal } 65 \mathrm{k} \text { and } \\
\text { at } 10 \% \text { confidence level. }\end{array}$ & For freight rates in $\$ \rightarrow \mathrm{RW}$ accepted. & $\begin{array}{l}\text { grain } 55 \mathrm{k} \text { at } 5 \% \text { and } 10 \% \text { confidence } \\
\text { levels; with no trend stationarity } \\
\text { exists. }\end{array}$ \\
\hline
\end{tabular}

Source: author from [60].

$\mathrm{t}+1$, and vice versa ("pink noise"). This is a basic result in the "rescaled range analysis" [62], which generalized Einstein's 1905 proof of randomness and RW...

Tvedt [60] further found that RW is rejected for BPI, at 5\% confidence level, expressed in Yen (Table 1).

As shown, his findings were contradictory and confusing.

Tvedt [63] found that prices processed by an equilibrium model are closely related to a "mean reverting stochastic one". Then a "stochastic optimal control problem"-covering the effect on freight rates of the rigidities in yard capacities-was presented. Finally, the optimal investment and restructuring policies, under switching costs, were derived.

Kavussanos and Visvikis [64] used data "over the counter"33 for $\mathrm{FFA}^{34}$ in a VEC model-GARCH to see the "lead-lag" relationships in returns and volatilities between spot and future markets. Visvikis et al. [65] examined how FFA affects the spot market price volatility in 2 dry bulk shipping routes. Using "control variables", they found that FFA trading, had no detrimental effect on spot market. They used time-varying volatility to examine the behavior of the dry bulk freight rates. The empirical distributions of stock returns exhibited fat tails and spiked peaks, as well persistence in variance. ARCH, however, provided a good approximation to many stock return series.

Chen and Wang [66] applied Nelson's EGARCH (exponential GARCH) model to examine the leverage effect in shipping (data: 27/04/1999 to 31/07/2003). The asymmetric impact between "past innovation" and "current volatility", they concluded, is inherent. Adland and Cullinane [67] rejected the applicability of the "expectations theory" in bulk shipping. They showed that risk premiums are time-varying and dependent systematically on freight market conditions, and on the duration of time charter. It is true that charterers believe that a longer time charter might "bring" them a marine accident...

If we want now to compare further the 2 mentioned above periods, we can say that the most and many outstanding issues in shipping economics were covered by doctoral students etc. emerged at the time coinciding with mature structural changes in Econometrics, like the models of ARCH and GARCH, but also of co-integration.

In the $2^{\text {nd }}$ period, most issues were already covered and thus few subjects left

\footnotetext{
${ }^{33}$ This is a market in securities not regulated by an exchange.

${ }^{34} \mathrm{FFA}=$ forward freight rate agreements.
} 
for research this period like: seasonality, rational expectations, EMH and stationarity-very difficult problems. Moreover, new variations of GARCH applied and the interest extended to FFA (futures).

Econometrics $^{35}$ did not appear in all economic shipping schools in 1990s, unlike Statistics. Econometrics is a science emerged to enable Economics to verify the results of economic measures-using statistics-miming Physics. Physics was always admired by Economics... with its laws, harmony and reliability.

\section{Further Information on Above Models}

The additional information about the models presented above is as follows (Table 2).

As shown, 5 models supported the existence of RW and 1 rejected it. One also doubted EMH and RE.

\section{Button's Critique of Maritime Economists [1]}

\subsection{The Overall Picture (Figure 1)}

As shown, McConville J. [68], was recognized [by 1] as the one who wrote thoroughly the "neoclassical maritime economics", whatever this means. Also, $\operatorname{Thorburn}^{36}$ (1960) was recognized [by 1] as the "all-time classic". Worth noting is to note the $1^{\text {st }}$ "liner cartel" in 1875 , between India and UK, which was established by English. Moreover, new dangers emerged in international shipping since that time in the form of threatening the: safety, security, ownership (piracy) and sea (pollution)!

In addition, new institutions established to regulate shipping, on top of flag administrations, as being an international industry concerning everybody, for bad or for good: UNCTAD, IMO (=international maritime organization), and EU. In addition, the shipping economic environment changed by the rule $40-40-20^{37}$ and by globalization. Shipping serves international "seaborne trade" and whatever helps this to grow is beneficial, like dismantling tariffs applied some years ago.

In the economics of shipping, certain issues drew the attention of maritime economists par excellence against others: prices, production, incentives and resource allocation. We will discuss them below.

\section{2. "Shipping", "Maritime" and "Marine" Economics: The Confusing Terms}

Maritime economists [like 1] are confused over the connection between the above 3 terms. These 3 make one science, and should not be the cause of a

${ }^{35}$ The first and only book in maritime econometrics appeared in 1990 in $2^{\text {nd }}$ edition written by Marlow and Evans.

${ }^{36}$ Thorburn, T. (1960) Supply and demand of water transport: studies in cost and revenue, structure of ships, ports and transport buyers w.r.t. their effects on supply and demand of water transport of goods, Business Research institute, Stockholm School of Economics.

${ }^{37}$ This rule was an effort of UNCTAD to allocate cargoes in containerships in a more just manner. $40 \%$ allocated to ships of the exporting country; $40 \%$ for ships of the importing country and $20 \%$ for the ships of cross-traders like Greece. 
Table 2. Additional information about the models presented above, 1996-2005.

\begin{tabular}{|c|c|c|c|c|c|}
\hline $\begin{array}{c}\text { Serial } \\
\text { Number }\end{array}$ & Year/Journal & Author(s) & Main subject & Econometric method & Remarks \\
\hline 1 & $\begin{array}{c}1996 \\
\text { MP\&M }\end{array}$ & Kavussanos M & Bilateral seaborne-trade flows & $\begin{array}{l}\text { Neoclassical optimization; using } \\
\text { objective function (=CRESH) }\end{array}$ & 1971 \\
\hline 2 & $\begin{array}{l}1996 \\
\text { TEP }\end{array}$ & Kavussanos M & $\begin{array}{l}\text { Volatility in dry cargo freight rates, } \\
\text { 1973-1992; TC for Cape, Panamax } \\
\text { and Handy }\end{array}$ & $\begin{array}{c}\text { Reduced form; } \\
\text { Co-integration; order 1; RW }\end{array}$ & $\begin{array}{l}\text { Granger 1981; 1983; } \\
\text { Engle \& Granger } \\
\text { 1987; Johansen } 1988\end{array}$ \\
\hline 3 & $\begin{array}{l}1996 \\
\text { LTR }\end{array}$ & Kavussanos M & $\begin{array}{l}\text { Risk among sizes (tankers); in spot } \\
\text { and time charters; and in dry bulk } \\
\text { freight market }\end{array}$ & ARCH; GARCH & $\begin{array}{l}\text { ARCH (Engle 1982); } \\
\text { GARCH (1986) } \\
\text { (Bollerslev) }\end{array}$ \\
\hline 4 & $\begin{array}{c}1996 \\
\text { MP\&M }\end{array}$ & $\begin{array}{l}\text { Grammenos } \\
\& \text { Marcoulis }\end{array}$ & $\begin{array}{l}\text { Company's beta- } \beta \text { relationship to stock } \\
\text { exchange, leverage, average fleet age } \\
\text { and dividends, 1989-1993 }\end{array}$ & OLS; a cross section regression & $\begin{array}{l}1973 \text { "Fama and } \\
\text { MacBeth" }\end{array}$ \\
\hline 5 & $\begin{array}{c}1996 \\
\text { MP\&M }\end{array}$ & Berg-Andreassen & $\begin{array}{l}\text { BFI } 1985-1988,1980-1989 ; \\
2^{\text {nd }} \text { hand prices of dry bulk }\end{array}$ & $\begin{array}{l}\text { Co-integration; } \\
\text { Johansen } 1990\end{array}$ & \\
\hline 6 & $\begin{array}{c}1996 \\
\text { MP\&M } \\
\text { (Comment on) }\end{array}$ & Glen & $\begin{array}{l}\text { The relationship between the level of } \\
\text { shipping gross investment and } \\
\text { incentives (1963-1993; 1963-1987) }\end{array}$ & $\begin{array}{l}\text { Co-integration; ECM; } \\
\text { time series; OLS }\end{array}$ & $\begin{array}{l}\text { Critique against } \\
\text { McWilliams et al., } \\
\text { 1995; Marlow 1991; } \\
\text { Goss \& Marlow, } \\
\text { 1997; Gardner, } 1999\end{array}$ \\
\hline 7 & $\begin{array}{c}1996 \\
\text { MP\&M }\end{array}$ & Chang \& Chang & BIFFEX’s predictability (1985-1993) & Linear regression; OLS & $\begin{array}{l}\text { Autocorrelation; } \\
\text { Durbin/Watson } \\
\text { 1976; "spurious } \\
\text { regression" }\end{array}$ \\
\hline 8 & $\begin{array}{r}1997 \\
\text { TR, A }\end{array}$ & $\begin{array}{l}\text { Veenstra } \\
\text { \& Franses }\end{array}$ & $\begin{array}{l}\text { Monthly freight rates, 1983-1993, } \\
\text { dry cargo, logarithms }\end{array}$ & $\begin{array}{c}\text { Series non-stationary at } 1 \% \\
\text { confidence level; co-integration } \\
\text { of order } 1\end{array}$ & $\begin{array}{l}\text { ADF with no trend; } \\
\text { RW }\end{array}$ \\
\hline 9 & $\begin{array}{l}1997 \\
\mathrm{AE}\end{array}$ & Kavussanos, M & $\begin{array}{l}\text { Volatility in } 2^{\text {nd }} \text { hand prices of different } \\
\text { sized dry bulks (monthly, 1976-1995) } \\
\text { seasonal data-logs; time charters }\end{array}$ & $\begin{array}{l}\text { Integration no } 1 ; \\
\text { Time charters found } \\
\text { stationary }\end{array}$ & $\begin{array}{c}\text { RW } \\
\text { Contra with } \\
\text { Kavussanos (1996) } \\
\text { on volatility }\end{array}$ \\
\hline 10 & $\begin{array}{c}1997 \\
M P \& M\end{array}$ & Li \& Parsons & Forecasting tanker freight rates & “Artificial Neural Networks" & $\begin{array}{l}\text { Non-linear } \\
\text { regression }\end{array}$ \\
\hline 11 & $\begin{array}{c}1997 \\
\text { MPM }\end{array}$ & Berg-Andreassen & $\begin{array}{l}\text { Spots vis-à-vis time charters } \\
\text { (BFI)-changes }\end{array}$ & $\begin{array}{l}\text { Co-integration no 1; ADF; } \\
\text { Johansen 1988; Koyck model }\end{array}$ & $\begin{array}{c}\text { Normal distribution } \\
\text { at } 10 \% \text { confidence } \\
\text { level. All previous } \\
\text { models rejected; } \\
\text { RW }\end{array}$ \\
\hline 12 & $\begin{array}{c}1997 \\
M P \& M\end{array}$ & Glen & $\begin{array}{l}\text { Monthly observations of tanker and } \\
\text { dry cargo markets; Co-integrated } \\
\text { inefficient? } 2^{\text {nd }} \text { hand log ship prices, } \\
1979-1995 \& 1979-1988 \text {, are } \\
\text { co-integrated of order } 1\end{array}$ & & RW \\
\hline 13 & $\begin{array}{c}1997 \\
\text { MP\&M }\end{array}$ & Glen \& Rogers & Dry cargo time series of Capes & $\begin{array}{c}\text { Co-integration } \\
\text { (Johansen, 1988); VCM }\end{array}$ & \\
\hline 14 & $\begin{array}{c}1997 \\
M P \& M\end{array}$ & $\begin{array}{l}\text { Kavussanos \& } \\
\text { Marcoulis }\end{array}$ & $\begin{array}{c}\text { Water transportation Companies' } \\
\text { performance in NYSE, 1985-1994, } \\
\text { 1984-1995, and risk; betas }\end{array}$ & $\begin{array}{l}\text { CAPM; co-integration, } \\
\text { stationarity }\end{array}$ & $\begin{array}{l}\text { Average beta }<\text { than } \\
\text { market's; stocks not } \\
\text { underpriced; no risk } \\
\text { for 1984-1989; } \\
\text { "alpha" affected }\end{array}$ \\
\hline 15 & $\begin{array}{r}1997 \\
\text { TR, E }\end{array}$ & $\begin{array}{l}\text { Kavussanos \& } \\
\text { Marcoulis }\end{array}$ & $\begin{array}{l}\text { Lower betas for US Water } \\
\text { transportation }\end{array}$ & & \\
\hline
\end{tabular}


16

$$
\begin{array}{ll}
1997 & \text { Tvedt } \\
\text { MPM } &
\end{array}
$$

17

1998

MP\&M

Glen \& Martin

$$
1998
$$

18

$$
\text { MP\&M }
$$

1998

19

MP\&M

20

$$
1999
$$$$
\operatorname{MP} \& M(*)
$$

21

$1999 \quad$ Kavussanos \&

Futures Markets

22

$$
1999
$$

MP\&M

23

$$
2001
$$

TR, E

2002

MP\&M

$$
24
$$

Dikos \& Papapostolou

25

26

27

28
2002

MP\&M

2003

MP\&M

2003

ME\&L

$$
2004
$$

Banking \&

Finance

Kavussanos \&
Alizadeh

Tvedt

29

$\begin{array}{ll}2004 & \text { Visvikis et al. } \\ \text { TR, E }\end{array}$

TCE spots; VLCC; lay-up and scrapping "options" to spot market

Risk connection with size and between

spots and time charters of tankers; use of proxies

\section{Stocks of 14 water transportation companies, 1984-1995 NYSE}

Owners to decide chartering strategies in bulk shipping

A two tier tanker market due to OPA 1990

Unbiased BIFFEX future prices; time-varying and constant hedge ratios

The relation between spot and period dry bulk freight rates

Seasonality in dry bulks; over sizes, contract duration and market conditions

Volatility over 4 sizes of tankers, 1980-1993, spots and time charters

Dry cargo ship prices market efficient? 1976-1997

Stationarity in spot freight rates; 1984-1999; TCE 1988-1999; $2^{\text {nd }}$ hand prices; new-building prices, 1970-1999; three sizes; in \$ and YEN

Prices are mean reverting stochastic; freight rates on rigidities in yard capacity

FFA over the counter; lead-lag relationships in returns \& volatilities of spots and futures

FFA's effect spots and their volatility, in 2 dry bulk routes
Geometric mean reversion; uncertainty

Reduced form; GARCH; MLFI; non-stationarity

CAPM; multiple regressions

\section{CAPM}

$$
\text { Simulation }
$$

\section{GARCH; GARCH-X}

Present Value model; VAR

"Unit root" test

Shiller, 1989

GARCH-M-in the mean; Campbell \& Shiller 1987; 1988

ADF with no trend; Bjerksund \& Ekers, 1995

Optimal stochastic control

VEC model-GARCH

Control variables; time-varying volatility; ARCH
Demand insensitive to freight rates; Supply inelastic in short run with idle ships

Systematic differences of risk; fat tails; leptokurtosis; certain exceptions

Betas $=0.94-0.95$

Dec. 1994; due to COFR

BFI follows RW;

GARCH-X better for falling risks

There is a term structure; doubt for EMH

Spots more volatile, except Aframax;

larger vessels more volatile, except Aframax. Period freight rates appeared to be perfect foresights of future rates

BFI; stationary; RW rejected for freight rates and $2^{\text {nd }}$ hand prices (Table 1)

Optimal investment \& restructuring policies under switching costs

No detrimental effect on spots; fat tails; spiked peaks; persistent variances 


\section{Continued}

\begin{tabular}{|c|c|c|c|c|c|}
\hline 30 & $\begin{array}{c}2004 \\
\text { MP\&M }\end{array}$ & Chen \& Wang & Leverage effect; 1999-2003 & $\begin{array}{l}\text { EGARCH due to Nelson } \\
\qquad(1991)\left({ }^{(*}\right)\end{array}$ & $\begin{array}{c}\text { current volatility = } \\
\text { asymmetrical; } \\
\text { inherent in these } \\
\text { markets }\end{array}$ \\
\hline 31 & $\begin{array}{l}2005 \\
\text { TEP }\end{array}$ & $\begin{array}{l}\text { Adland \& } \\
\text { Cullinane }\end{array}$ & The ET in bulk shipping rejected & & $\begin{array}{l}\text { Risk premium time } \\
\text { varying depending } \\
\text { on freight market } \\
\text { conditions \& } \\
\text { duration of time } \\
\text { charters }\end{array}$ \\
\hline 32 & $1995 \mathrm{MP} \& \mathrm{M}\left({ }^{\star}\right)$ & Tamvakis, M.N. & $\begin{array}{l}\text { Two-tier spot freight market } \\
\text { for crude oil tankers }\end{array}$ & & $\begin{array}{c}\text { See also Strandenes } \\
\text { S (1999) }\end{array}$ \\
\hline 33 & 1989 TEP & Hale and Vanags & Spot and period rates; dry bulk & & \\
\hline 34 & 1992 MP\&M & Hale and Vanags & $2^{\text {nd }}$ hand ship market & Efficiency; co-integration & \\
\hline 35 & 1995 & Bjerksund \& Ekern & Cash-flows in shipping & $\begin{array}{l}\text { Mean reverting; } \\
\text { Real options }\end{array}$ & \\
\hline 36 & 1998 LSE & Kavussanos M & Freight risks in tankers & & \\
\hline
\end{tabular}

Journals: MP\&M = Maritime Policy \& Management; TEP = Transport Economics \& Policy; LTR = Logistics and Transport review; TR = Transportation Research; AE = Applied; Economics; ME\&L = Maritime Economics \& Logistics. $\left.{ }^{\star *}\right)$ Nelson D, (1991), onditional heteroscedasticity in asset returns: a new approach, Econometrica, 59, 347-370.

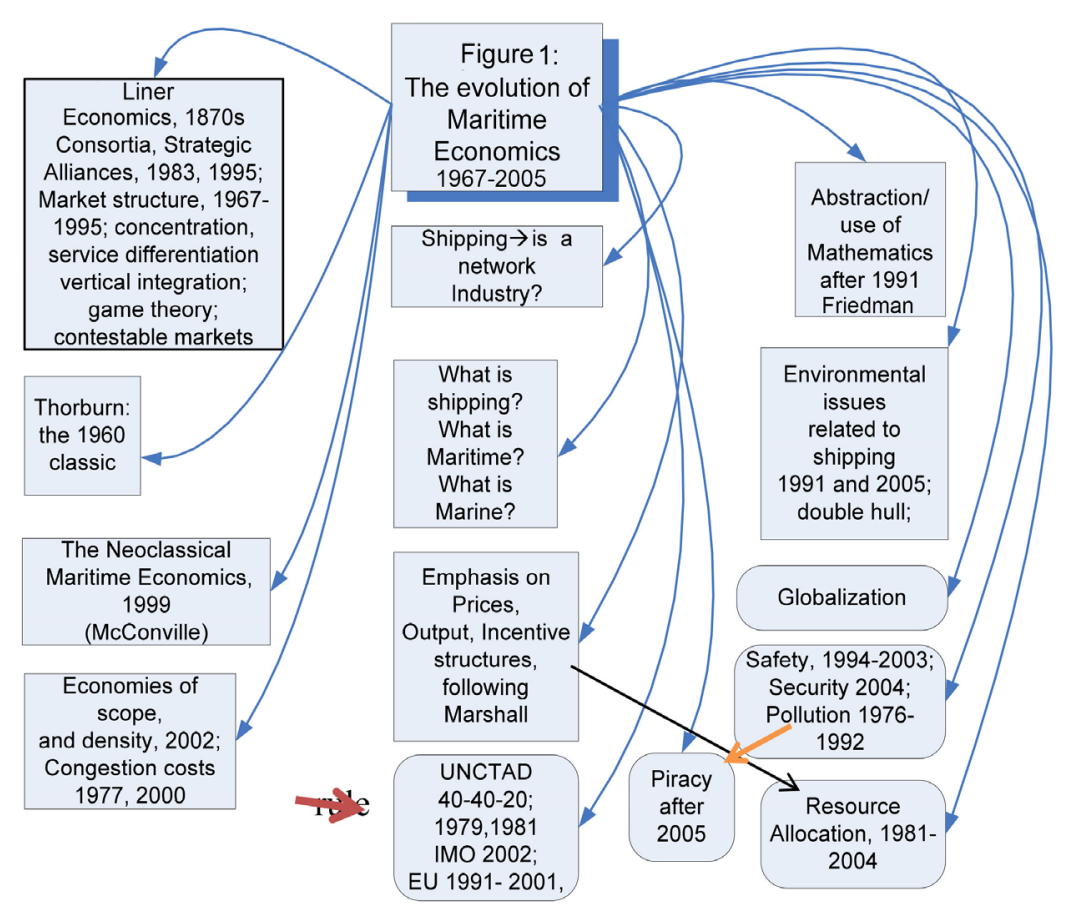

Figure 1. A chronological picture of Maritime Economics from 1967 till 2005. Source: Inspired by Button (2005) [1].

controversy but the cause of harmony. As shown in Figure 2, the wider circle is marine economics-including maritime economics and economics of shipping (plus the economics of shipbuilding). Most people ignore that shipbuilding economics belongs to shipping one. 


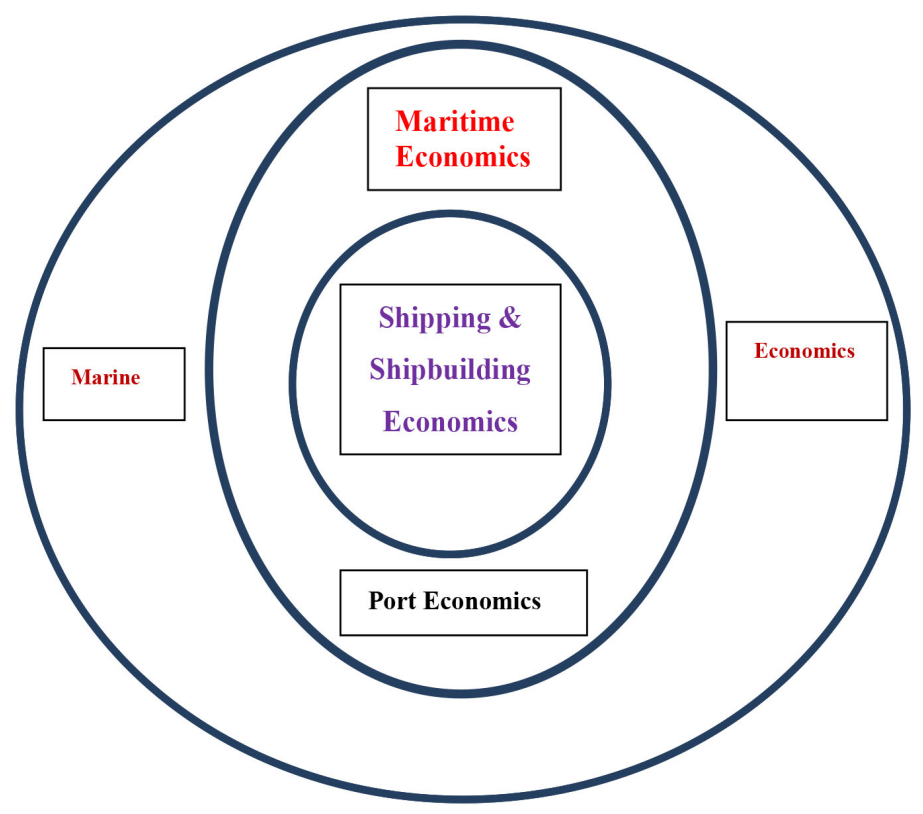

Figure 2. Marine, Maritime and Shipping Economics circles. Source: author.

Goulielmos [69] [70] and Goss [71] cleared-out the above 3 terms: "Marine ${ }^{38}$ economics" deals with at least 7 additional sea industries (=sea tourism; cruising; sea resources; coastal management; defense/Navy, fisheries etc.), and not exclusively with their economic issues, as this is the only science dealing with them. This science created by the "Law of the Sea" (LoS) in 1982. Nations consist-after 1982 1) of land (which was and is theirs, including a (territorial) sea/air zone of 12 miles vis-à-vis former 6) and 2) of a sea as far as EEZ (having the right to exploit those, including continental shelves). Islands with economic life have a continental shelf.

\subsection{Button's Main Critique of Maritime Economists [1]}

Button criticized maritime economists on 4 counts: 1) that the proper approach to maritime economics had to be more holistic-moving beyond conventional, largely neoclassical, economic tools, meaning to set things within the larger

${ }^{38}$ Known also as "Sea Affairs", meaning "Economics of Sea". This science covers (sea) environment, exclusive economic zone-EEZ, and another 5 zones, continental shelf, and all activities taking place on and inside coasts and inside sea from coast (the Chinese e.g. determined 20 kilometers inside and outside coast for "coastal zone"). LoS gave right to coastal nations to exploit sea given that it can provide resources, of which more important are: manganese rocks, oil, gas and fish. At that time, (1982), in UN joined many emerging independent poor nations, who had to rely exclusively on fish for their survival. E.g. the thin-populated Norway especially, and UK, to a lesser degree, prospered on oil and gas extracted from (North) Sea... as a result, UK saved the $£$ and Norway doubled its standard of living. The new dogma cancelled the older dogma that "everything in the sea can be exploited by everybody, as it belongs to all" (excluding territorial sea of course), which suited advanced powerful nations having the means... Turkey, which did not ratify LoS, threatens with war Greece, if last's territorial sea is extended to 12 miles from 6 now (10 in the air). Turkey also disputes that Greek Islands have a continental shelf. The greater problem, however, of Turkey is with Cyprus' EEZ, where explorations for oil and gas take place for some time now. 
framework of "institutional economics"39. Button argued that this is so as shipping is a network industry involving physical, spatial and temporal networks.

2) The way maritime economists treated shipping issues since 1995, or even before, left certain gaps. The weaknesses in understanding shipping markets-including the implications of regulating markets and how actors are involved in them to reach their decisions-were long standing, and provided generic challenges.

3) In very few instances maritime problems were at the root of new economic thinking. There also was an unquestionable, and perhaps undesirable, move towards increased abstraction from the use of mathematics in economics since the time of Friedman (in 1991), but this was not followed by maritime economists. 4) Maritime economists needed time to understand shipping economics, transportation and environmental issues. Shipping played a limited role in the development of economic thinking and it was rather a recipient of ideas than a generator. Late Professor Goss $\mathrm{R}$ was only mentioned as providing an early history of the development of shipping economics [71], and nothing more, despite his contribution to science. We suspect that Button wanted to undervalue European maritime economists in comparison to USA or Canadian ones...

\subsection{Button's Comments on Liner Economics [1]}

The potential market power of conference lines stimulated the thinking about regulating them. Matters of shipping costs, impinged upon the neatness of the "Ricardian trade theory", had a minimum impact. These were all in all the seminal shifts of economic thinking associated with shipping problems. In economic journals-since 1975-few papers dealt with shipping... This is true as shipping has its "own" journals. One must not forget that two Nobel winners, used to be at their early steps shipping economists (Tinbergen, 1969 and Koopmans, 1975).

The "literature" of shipping economics focused mainly on 3 issues: prices, output and incentives, (the 3 typical neo-classical economic questions), which formed also the basis of Marshall's Principles. But technical, more advanced, and far more quantitative can be found all right in the $19^{\text {th }}$ century journals... while an emerging economic literature on shipping towards social analysis is of more enduring interest.

The evolving structure of co-ordination of shipping activities due to conferences, and later to consortia and strategic alliances, occurred discretely (in containership market). In the larger integrated supply chains, ties exist of shipping with other elements in the logistics system, e.g. with ports and others.

${ }^{39}$ This is an economic analysis emphasizing the role of social, political and economic organizations in determining economics. Such theories advanced, between 1874 and 1948, by Veblen and Mitchell and followed later by Myrdal. The economist and Prime Minister of Greece late Professor Andreas Papandreou stated (1981) that "Greece's problem is not economic, but political”. Keynes in 1936 was the first to introduce 3 basic psychological laws in "macro-economics" (Goulielmos, 2018), [72]); Coase joined this theory in 1998 with his seminal paper in "American Economic Review". 
UNCTAD with its 40-40-20 rule and the creation of the EU and its maritime policy, are longer-term changes in largely legal arrangements. The traditional "Pigouvian" externalities are areas of interest in shipping with maritime pollution and safety, in an embryonic literature by 2005 . The gradual move to globalization is shipping development. Globalization, however, is now (end 2018), threatened by Trump administration in USA.

Network economics apply to maritime industry as its output is not durable, and normally a significant infrastructure is required. Benefits arise from scope and density [73]. The ability to channel traffic through hubs created the economies of scope and density in maritime economics.

\subsection{Shipping: A Highly Regulated Industry [1]}

Shipping acts within a cloud of regulations. The fewer came from UNCTAD [74] and the plethora from IMO [75]. In addition, EU emerged in determining as well the ways in which maritime activities should be performed [76]. The focus of EU was on limiting "state aid" and on abolishing "cabotage" 40 . Much of the up to 2005 concern of EU was about environmental issues, including "double hulls" of ships and "security" of ports and ships after 2001 (twin-towers terrorist disaster).

Piracy was-and still is-a major concern to shipping industry, though its economic literature was scant by 2005 . The security ${ }^{41}$ issue arose when ships and their cargoes or containers can be used as weapons. In the past, ships hijacked and attacked by manned-suicide-vessels. Maritime safety, unlike maritime security, presents a fairly extensive literature [77] by 2005. This is so as safety requirements appeared first, by ISM (international safety management) Code, in 1996. Moreover, shipping and ports were considered responsible for accidental spillages. Unfortunately, the issue of the sea environment treated from engineering point of view facing ship's size, design and inspection [78].

\subsection{Other Liner Economics Issues [1]}

An issue was the nature and rationale of contracts starting with conferences and moving through consortia and alliances in containerships. Based on economies of scope and scale, there is a rationale for having large shipping companies (Clyde and Reitzes [79]).

Market structure occupied maritime economists since 1967 with Prof. Sturmey $S$ contributing to the literature about liner conferences. A number of papers dealt then with cartels: Deakin and Seward [80]; Gilman [81]; Andrew's market theory [82], and Felner's oligopoly theory [83]. Tramp shipping markets emerged as competitive [84]. But, the empirical testing of the theories remained problematic due to data's limitation and to the concept of "empty core" (="equilibrium relative prices" in game theory).

\footnotetext{
40"Cabotage" is the exclusive right of coastal ships to serve a nation's transport the flag of which they flow.

${ }^{41} \mathrm{An}$ issue which peaked in 2001 with the twin towers disaster in USA. The international law against terrorism legislated in 2004.
} 
The network nature of the industry and its service nature ignored, while emphasis was on concentration ratios, product differentiation and vertical integration. Some used the concept of neoclassical efficiency, others looked at game theory (emerged in 1944-e.g. the "empty core" notion is due to Edgeworth). Transaction costs also ignored.

\subsection{Resource Allocation in Shipping Industry, 1981-2004 [1]}

The issue of resource allocation occupied-thereafter-heavily maritime economists (Figure 3).

In this issue, Haralambides and Veenstra [85], provided a literature dated back to Adam Smith and Alfred Marshall, in particular, dealing with "marginal conditions". In the issue of costs, papers have regularly published since 1965 dealing with various cost components and structures of ship-owners' costs. This attracted most of the attention of research. In particular, there were examined: fleets' scale effects Cullinane and Khanna [86]; supply elasticities tied to costs [87] and $2^{\text {nd }}$ hand vessels [88].

Many of the earlier papers on costs rested on accounting or used a limited econometric analysis, employing mainly linear and Cobb-Douglas functions. In 1986-1987 research used trans-log and quadratic specifications [89]. Shipping economists did not fail to deal with density economies as well [90]. Maritime research and especially quantitative one was blocked due to lack of good cost data and propriety.

In the issue of Demand, it is noted that since 1985 the interest turned increasingly towards "supply-chain logistics" [91]. Financial savings can be obtained through a better and more integrated management via supply chain [92].

Finance, marketing etc., became more sophisticated and technology improved as well the communications systems; the global move to more liberalized economic regulatory regimes and freer international trade took place. Logistics-meaning to maximize return over the value chain-appeared as essential element. This is something that needs more attention in a formal vertical integration.

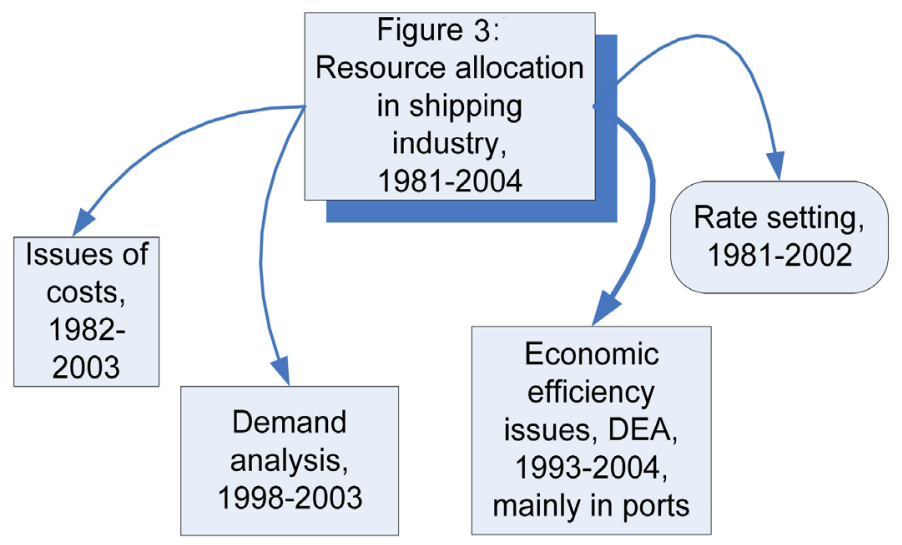

Figure 3. Resource allocation. Source: Inspired by Button (2005) [1]. 
In the issue of Rates, this was one of the most popular subjects, as we saw. Initial works dealt with dry bulk markets [14] [34] [35] [36] and with tankers [93] [94]. Works tried to show the way risk is embodied into the rates, and how contracts were established. It was believed that short-term rates were a function of the current condition of supply and demand, while in the long-term were based on expectations about future short-term rates. But Kavussanos and Alizadeh [59] and Veenstra [30], disputed this.

In the issue of differential rates for space on particular vessels, this was almost ignored. Conferences originally maintained such rate structures to capture as much economic rent as possible. Unitization (containerization), however, since 1960s, brought major changes in cost structure and operations of liners [95]; the yield management emerged as a challenge [96]. In the issue of economic efficiency, this started as one of inefficiency in allocation, which brought issues of motivation and institutional structures in shipping and of the quality of services and agency theory.

Econometric and programming works were applied to measure efficiency, which initially dealt with comparisons between tramp and conference rates in similar routes and cargoes [97]. Then a new methodology emerged: the "Data Envelopment Analysis"-(DEA), especially for port efficiency [98]. Worth noting is that DEAs do not allow testing statistical significance.

General economics helped shipping economics [99] and the after 1991 application of more powerful econometric tools, added quantitative knowledge. But this was a short term focus; maritime activity confined in Marshall's market period! [1]. The "longer term" evolvement of shipping was less certain by 2005 and data was questionable [100]. On top, one may add climatic change [101], making the life of maritime economists even harder.

\section{Further Research}

This paper has the limitation of describing a particular period, and thus has a limited time impact into the future. It seems to have a historical importance, quite useful for new research. Since this is a $2^{\text {nd }}$ paper of a survey type in this Journal, one must read them together (for 2006-2016). Another limitation is that the one making the survey must be more capable in the subjects dealing with and this is not always guaranteed. The most important point of this paper is its basis, i.e. its basis which is econometrics is in the making... What we consider valid, it is out-turned by newer research and thus past models are false-as happened already. We cannot wait till econometrics settles down to carry our research! So, be careful.

\section{Concluding Remarks}

The 1996-2005 decade was very productive for maritime modeling. The production quantity, however, did not follow quality. Maritime economists unfortunately were victims of the "spurious regression" phenomenon and of not testing 
for stationarity. Also, they followed the advances in general econometrics, but with certain long year-delays of 14 years. Five papers clearly supported the idea that RW prevails in maritime markets. Tvedt [60] reached mixed results, where RW was accepted in 3 situations and rejected in $4 \ldots$

Our applications showed [55], however, that most, if not all, freight rate indices, are persistent, i.e., maritime time series follows trends. If it increases in $t-$ 1 , it will do so in $t+1$ (="black noise"). But what confused maritime economist, we believe, is data's frequency. Daily or shorter-weekly and monthly figures show persistence; yearly figures follow RW! This adds another difficulty in helping shipowners. This must be cleared-out by future research. Mandelbrot and Hudson [23] believed that like something which is boiling, also events (time series) boil down as time goes-by, and things smooth-out becoming normal (distributed).

A critique made against Vergottis [102] and Strandenes [103], was that they ignored the stochastic properties of the variables and used "spurious regression" [104]. Moreover, Hale and Vanags [40] and Glen [38] failed to recognize that the existence of co-integration is a necessary, but not a sufficient condition for EMH. The possibility of excess profit cannot be excluded in shipping markets. We believe this to be true for short run, which can be long in calendar time (e.g. 2003-2008). Coefficient restrictions are also needed.

Moreover, the period of investigation must be "properly long" to examine a full shipping cycle. The above models assumed a short run cycle of 6 or 9 years relying on Stopford [105], ignoring any long term cycles of 20 years or so. Moreover, unfortunately, the Jarque-Bera test [22] all the time indicated significant departure from normality. Also, serial correlation was found in above models.

Goulielmos [106] argued that the Aframax tankers new-building prices showed two cycles: one of 2 years and two months and one 16 years and 3 months, over a time series of about 32 years. The $2^{\text {nd }}$ hand market for Aframax ship prices had also two cycles: one 2 years and 2 months and one $61 / 2$ years.

On empirical grounds, the author argued that new-building prices are higher than $2^{\text {nd }}$ hand ones. But this was not so during the 2003-2008 boom. Extremely high spot, and not only, rates, demand tonnage here and now, as well as something that shipbuilding cannot do; there, only $2^{\text {nd }}$ hand ships are left as ready in a short time to gain these high rates. This is surely a myopic policy, but who can predict the proper timing?

Goulielmos [107] proved, we believe, beyond any stereotypes that it is not the size of a ship or the duration of her charter that matters for risk, but the strength of demand against the supply, which each size and type of charter faces. $\mathrm{He}$ found Cape less risky than Panamax, which is contradictory to what most of the previous research argued! Why? Reason is shown in Appendix.

\section{Conflicts of Interest}

The author declares no conflicts of interest regarding the publication of this paper. 


\section{References}

[1] Button, K. (2005) Shipping Economics: Where We Are and Looking Ahead from an Institutional Economics Perspective. Maritime Policy \& Management, 32, 39-58.

[2] Kavussanos, M.G. (1996) Highly Disaggregated Models of Seaborne Trade. An Empirical Model for Bilateral Dry-Cargo Trade Flows in the World Economy. Maritime Policy \& Management, 23, 27-43. https://doi.org/10.1080/03088839600000050

[3] Chang, Y-T. and Chang, H.B. (1996) Predictability of the Dry Bulk Shipping Market by BIFFEX. Maritime Policy \& Management, 23, 103-114. https://doi.org/10.1080/03088839600000068

[4] Grammenos, C.TH. and Marcoulis, S.N. (1996) A Cross-Section Analysis of Stock returns: The Case of Shipping Firms. Maritime Policy \& Management, 23, 67-80. https://doi.org/10.1080/03088839600000053

[5] Engle, R.F. (1982) Autoregressive Conditional Heteroscedasticity with Estimates of the Variance of United Kingdom Inflation. Econometrica, 50, 987-1008. https://doi.org/10.2307/1912773

[6] Peters, E.E. (1994) Fractal Market Analysis: Applying Chaos Theory to Investment \& Economics. A Wiley Finance Edition, John Wiley \& Sons, Hoboken.

[7] Granger, C.W.J. (1981) Time Series Data and Econometric Model Specification. Econometrics, 16, 121-130. https://doi.org/10.1016/0304-4076(81)90079-8

[8] Granger, C.W.J. (1983) Co-Integrated Variables and Error Correction Models, UCSD, Discussion Paper: 83-13a.

[9] Engle, R.F. and Granger, C. (1987) Co-Integration and Error-Correction: Representation Estimation and Testing. Econometrica, 55, 251-276. https://doi.org/10.2307/1913236

[10] Johansen, S. (1988) Statistical Analysis of Co-Integrating Vectors. Economic Dynamic and Control, 12, 231-254. https://doi.org/10.1016/0165-1889(88)90041-3

[11] Bollerslev, T. (1986) Arch Model in Finance. Econometrics, 31, 307-327. https://doi.org/10.1016/0304-4076(86)90063-1

[12] Bollerslev, T., Chou, R. and Kroner, K. (1990) ARCH Modeling in Finance: A Review of the Theory and Empirical Evidence. Unpublished.

[13] Engle, R.F. and Bolleslev, T. (1986) Modelling the Persistence of Conditional Variances. Econometric Reviews, 5, 1-50. https://doi.org/10.1080/07474938608800095

[14] Kavussanos, M.G. (1996) Price Risk Modeling of Different Size Vessels in Tanker Industry Using Autoregressive Conditional Heteroscedasticity (ARCH) Models. Logistics \& Transport Review, 32, 161-176.

[15] Kavussanos, M.G. (1996) Comparisons of Volatility in the Dry-Cargo Ship Sector: Spot versus Time Charters and Small versus Larger Vessels. Transport Economics \& Policy, 30, 67-82.

[16] Beenstock, M. and Vergottis, A. (1993) Econometric Modeling of World Shipping. Chapman \& Hall, London.

[17] Berg-Andreassen, J.A. (1996) Some Properties of International Maritime Statistics. Maritime Policy \& Management, 23, 381-395. https://doi.org/10.1080/03088839600000096

[18] Johansen, S. (1990) Estimation and Hypothesis Testing of Co-Integration Vectors in Gaussian Vector Autoregressive Models. Econometrica, 59, 1551-1580. https://doi.org/10.2307/2938278

[19] Dickey, D.A. and Fuller, W.A. (1979) Distribution of the Estimators for Autoregres- 
sive Time Series with a Unit Root. American Statistical Association, 74, 427-431.

[20] Dickey, D.A. and Fuller, W.A. (1981) The Likelihood Ratio Statistics for Autoregressive Time Series with a Unit Root. Econometrica, 49, 1057-1072. https://doi.org/10.2307/1912517

[21] MacKinnon, J.G. (1990) Critical Values for Co-Integration Tests. In: Engle, R.F. and Granger, C.W.J., Eds., Long Run Economic Relationships. Readings in Co-Integration, Oxford University Press, Oxford, 267-276.

[22] Bera, A.K. and Jarque, C.M. (1982) Model Specification Tests: A Simultaneous Approach. Econometrics, 20, 59-82. https://doi.org/10.1016/0304-4076(82)90103-8

[23] Mandelbrot, B.B. and Hudson, R.L. (2006) The (mis) Behavior of Markets: A Fractal View of Financial Turbulence. Basic Books, New York.

[24] Glen, D.R. (1996) Comment: The Econometric Testing of Investment Incentives: A Co-Integrated Approach. Maritime Policy \& Management, 23, 201-207. https://doi.org/10.1080/03088839600000076

[25] McWilliams, D., Norwood, P. and Parfitt, A. (1995) Econometric Testing of Investment Incentives for Shipping: Update of the Marlow Model. Maritime Policy and Management, 22, 265-275. https://doi.org/10.1080/03088839500000064

[26] Marlow, P.B. (1991) Shipping and Investment Incentives: 3 Parts. Maritime Policy \& Management, 18, 123-138, 201-216, 283-311. https://doi.org/10.1080/03088839100000036

[27] Goss, R. and Marlow, P. (1997) Investment Incentives for British Shipping: A Comment on Recent Work. Maritime Policy \& Management, 24, 389-391. https://doi.org/10.1080/03088839700000046

[28] Gardner, B. (1999) Investment Incentives for British Shipping: A Further Comment. Maritime Policy \& Management, 26, 195-197. https://doi.org/10.1080/030888399287005

[29] Veenstra, A.W. and Franses, P.H. (1997) A Co-Integration Approach to Forecasting Freight Rates in the Dry Bulk Shipping Sector. Transportation Research A, 31, 447-458. https://doi.org/10.1016/S0965-8564(97)00002-5

[30] Veenstra, A.W. (1999) The Term Structure of Ocean Freight Rates. Maritime Policy \& Management, 26, 279-293. https://doi.org/10.1080/030888399286899

[31] Kavussanos, M.G. (1997) The Dynamics of Time-Varying Volatilities in Different Size $2^{\text {nd }}$ Hand Ship Prices of the Dry Cargo Sector. Applied Economics, 29, 433-444. https://doi.org/10.1080/000368497326930

[32] Li, J. and Parsons, M.G. (1997) Forecasting Tanker Freight Rate Using Neural Networks. Maritime Policy \& Management, 24, 9-30. https://doi.org/10.1080/03088839700000053

[33] Berg-Andreassen, J.A. (1997) The Relationship between Period and Spot Rates in International Maritime Markets. Maritime Policy \& Management, 24, 335-350. https://doi.org/10.1080/03088839700000042

[34] Beenstock, M. and Vergottis, A. (1989) An Econometric Model of the World Market for Dry Cargo Freight and Shipping. Applied Economics, 21, 339-356. https://doi.org/10.1080/758522551

[35] Beenstock, M. and Vergottis, A. (1989) An Econometric Model of the World Tanker Market. Journal of Transport Economics \& Policy, 23, 263-280.

[36] Hale, C. and Vanags, A. (1989) Spot and Period Rates in the Dry Bulk Market: Some Tests for the Period 1980-1986. Journal of Transport Economics and Policy, 23, 281-291. 
[37] Glen, D.R. (1997) The Market for Second-Hand Ships: Further Results on Efficiency Using Co-Integration Analysis. Maritime Policy \& Management, 24, 245-260. https://doi.org/10.1080/03088839700000029

[38] Fama, E. (1976) Foundations of Finance. Basic Books, New York.

[39] Hale, C. and Vanags, A. (1992) The Market of Second Hand Ships: Some Results on Efficiency Using Co-Integration Analysis. Maritime Policy \& Management, 19, 31-40. https://doi.org/10.1080/03088839200000003

[40] Glen, D.R. and Rogers, P. (1997) Does Weight Matter? A Statistical Analysis of the SSY Capesize Index. Maritime Policy \& Management, 24, 351-364. https://doi.org/10.1080/03088839700000043

[41] Kavussanos, M.G. and Marcoulis, S.N. (1997) Risk and Return of US Water Transportation Stocks over Time and over Bull and Bear Market Conditions. Maritime Policy \& Management, 24, 145-158. https://doi.org/10.1080/03088839700000066

[42] Kavussanos, M.G. and Marcoulis, S.N. (1997) The Stock Market Perception of Industry Risk and Microeconomic Factors: The Case of the US Water Transportation Industries versus Other Transport Industries. Transportation Research E, 33, 147-158. https://doi.org/10.1016/S1366-5545(97)00015-X

[43] Tvedt, J. (1997) Valuation of VLCCs under Income Uncertainty. Maritime Policy \& Management, 24, 159-174. https://doi.org/10.1080/03088839700000067

[44] Glen, D.R. and Martin, B.T. (1998) Conditional Modeling of Tanker Market Risk Using Route Specific Freight Rates. Maritime Policy \& Management, 25, 117-128. https://doi.org/10.1080/03088839800000023

[45] Johansson, A. (1995) Pricing Skewness and Kurtosis Risk on the Swedish Stock Market. MA Thesis, Lund University, Sweden.

[46] Kavussanos, M.G. and Marcoulis, S.N. (1998) Beta Comparisons across Industries-A Water Transportation Industry Perspective. Maritime Policy \& Management, 25, 175-184. https://doi.org/10.1080/03088839800000027

[47] Kavussanos, M.G. (1998) Freight Risks in Tanker Sector. Lloyd's Shipping Economist, 6-9.

[48] Berg-Andreassen, J.A. (1998) A Portfolio Approach to Strategic Chartering Decisions. Maritime Policy \& Management, 25, 375-389. https://doi.org/10.1080/03088839800000060

[49] Strandenes, S.P. (1999) Is There Potential for a Two-Tier Tanker Market? Maritime Policy \& Management, 26, 249-264. https://doi.org/10.1080/030888399286871

[50] Tamvakis, M.N. (1995) An Investigation into the Existence of a Two-Tier Spot Freight Market for Crude Oil Tankers. Maritime Policy \& Management, 22, 81-90. https://doi.org/10.1080/03088839500000034

[51] Kavussanos, M.G. and Nomikos, N.K. (1999) The Forward Pricing Function of the Shipping Freight Futures Market. Futures Markets, 19, 353-376.

https://doi.org/10.1002/(SICI)1096-9934(199905)19:3<353::AID-FUT6>3.0.CO;2-6

[52] Kavussanos, M.G. and Nomikos, N.K. (2000) Constant vs. Time Varying Hedge Ratios and Hedging Efficiently in the BIFFEX Market. Transport Research E, 36, 229-248.

[53] Campbell, J.Y. and Shiller, R.J. (1987) Co-Integration and Tests of Present Value Models. Political Economy, 95, 1062-1088. https://doi.org/10.1086/261502

[54] Campbell, J.Y. and Shiller, R.J. (1988) Stock Prices, Earnings, and Expected Dividends. Finance, 43, 661-676. https://doi.org/10.1111/j.1540-6261.1988.tb04598.x 
[55] Goulielmos, A.M. and Psifia, E.-M. (2007) A Study of Trip and Time Charter Freight Rate Indices: 1968-2003. Maritime Policy \& Management, 34, 55-67.

[56] Kavussanos, M.G. and Alizadeh, A.H. (2001) Seasonality Patterns in Dry Bulk Shipping Spot and Time Charter Freight Rates. Transportation Research E, 37, 443-467. https://doi.org/10.1016/S1366-5545(01)00004-7

[57] Dikos, G. and Papapostolou, N. (2002) Comment: The Assessment of Market Efficiency in the Shipping Sector: A New Approach. Maritime Policy \& Management, 29, 179-181. https://doi.org/10.1080/03088830110086347

[58] Shiller, R.J. (1989) Market Volatility. MIT Press, London.

[59] Kavussanos, M.G. and Alizadeh, A.H. (2002) Efficient Pricing of Ships in the Dry Bulk Sector of the Shipping Industry. Maritime Policy \& Management, 29, 303-330. https://doi.org/10.1080/03088830210132588

[60] Tvedt, J. (2003) A New Perspective on Price Dynamics of the Dry Bulk Market. Maritime Policy \& Management, 30, 221-230. https://doi.org/10.1080/0308883032000133413

[61] Bjerksund, P. and Ekern, S. (1995) Contingent Claims Evaluation for Mean Reverting Cash Flows in Shipping, Real Options in Capital Investment, Models, Strategy and Applications.

[62] Hurst, H.E. (1951) Long Term Storage Capacity of Reservoirs. Transactions of American Society of Civil Engineers, 116, 770-776.

[63] Tvedt, J. (2003) Shipping Market Models and the Specification of Freight Rate Processes. Maritime Economics \& Logistics, 5, 327-346. https://doi.org/10.1057/palgrave.mel.9100085

[64] Kavussanos, M.G. and Visvikis, I.D. (2004) Market Interactions in Returns and Volatilities between Spot and Forward Shipping Freight Markets. Banking and Finance, 28, 2015-2049. https://doi.org/10.1016/j.jbankfin.2003.07.004

[65] Visvikis, I.D., Kavussanos, M.G. and Batchelor, R.A. (2004) Over the Counter Forward Contracts and Spot Price Volatility in Shipping. Transportation Research E, 40, 273-296. https://doi.org/10.1016/j.tre.2003.08.007

[66] Chen, Y.S. and Wang, S.T. (2004) The Empirical Evidence of the Leverage Effect on Volatility in International Business Shipping Market. Maritime Policy \& Management, 32, 109-124. https://doi.org/10.1080/0308883042000208301

[67] Adland, R. and Cullinane, K. (2005) A Time-Varying Risk Premium in the Term Structure of Bulk Shipping Freight Rates. Transport Economics \& Policy, 39, 191-208.

[68] McConville, J. (1999) Economics of Maritime Transport: Theory and Practice. Witherby, London.

[69] Goulielmos, A.M. (2001) Matters of Definition: Maritime Economics Revisited. Collection of Papers, Volume in Honor of Late Prof. D Kodosakis, University of Piraeus, Pireas.

[70] Goulielmos, A.M. (2012) Editorial. Ocean Systems Management, 1, 227-237. https://doi.org/10.1504/IJOSM.2012.046500

[71] Goss, R. (2002) An Early History of Maritime Economics. Maritime Economics, 4, 390-404. https://doi.org/10.1057/palgrave.ijme.9100052

[72] Goulielmos, A.M. (2018) Economics: A Psychological Science. The Case-Studies of Eurozone, Global Economic Crisis and Greece, Modern Economy (Forthcoming). https://doi.org/10.4236/me.2018.911113 
[73] Bergantino, A.S. and Veenstra, A.W. (2002) Interconnection and Co-Ordination: An Application of Network Theory to Liner Shipping. Maritime Economics, 4, 231-248. https://doi.org/10.1057/palgrave.ijme.9100044

[74] Shah, M.J. (1981) The "UN Liner Code of Conduct": Some Key Issues Regarding Its Implementation. European Transport Law, 16, 491-554.

[75] Roe, M.S. (2002) Shipping Policy in the Globalization Era: The Interrelationship between International, Supra-National and National Shipping Policies. In: Grammenos, T., Ed., Handbook of Maritime Economics and Business, Lloy'd of London Press, London.

[76] Paixao, A. and Marlow, P. (2001) A Review of European Union Shipping Policy. Maritime Policy \& Management, 28, 187-198. https://doi.org/10.1080/03088830118389

[77] Stasinopoulos, D. (2003) Maritime Security-The Need for a Global Agreement. Maritime Economics \& Logistics, 5, 311-320. https://doi.org/10.1057/palgrave.mel.9100080

[78] Hopkins, T. (1992) Oil Spill Reduction and Costs of Ship Design Regulation. Contemporary Policy Issues, 10, 59-70. https://doi.org/10.1111/j.1465-7287.1992.tb00236.x

[79] Clyde, P.S. and Reitzes, J.D. (1995) Market Power and Collusion in the Ocean Shipping Industry: Is a Bigger Cartel a Better Cartel? Economic Inquiry, 36, 292-304. https://doi.org/10.1111/j.1465-7295.1998.tb01715.x

[80] Deakin, B.M. and Seward, T. (1973) Shipping Conferences: A Study of Their Origins, Development and Economic Practices. Cambridge University Press, Cambridge.

[81] Gilman, S. (1994) Contestability and Public Policy in Liner Short Sea Shipping, Competition Policy in Liner Shipping Edited by Molenaar and Van der Voorde E, Antwerp, UFSIA.

[82] Heaver, T.D. (1973) A Theory of Shipping Conference Pricing and Policies. Maritime Studies \& Management, 1, 17-30. https://doi.org/10.1080/03088837300000004

[83] Sturmey, S.G. (1967) Economics and International Liners Services. Transport Economics \& Policy, 1, 190-203.

[84] Wright, G. (1991) Freight Rates in the Tramp Shipping Market. Transport Economics, 18, 47-54.

[85] Haralambides, H.E. and Veenstra, A.W. (2000) Modeling Performance in Liner Shipping. In: Hensher and Button, K.J., Eds., Handbook of Transport Modeling, Oxford Pergamon Press, Oxford.

[86] Cullinane, K.P.B. and Khanna, M. (1999) Economies of Scale in Large Container Ships. Transport Economics \& Policy, 33, 185-207.

[87] Evans, J.J. (1988) The Elasticity of Supply of Sea Transport. Maritime Policy \& Management, 15, 309-313. https://doi.org/10.1080/03088838800000008

[88] Dikos, G. and Marcus, H.S. (2003) The Term Structure of Second-Hand Prices: A Structural Partial Equilibrium Model. Maritime Economics \& Logistics, 5, 251-267. https://doi.org/10.1057/palgrave.mel.9100084

[89] Tolofari, S., Button, K.J. and Pitfield, D. (1987) An Econometric Analysis of the Cost Structure of the Tanker Sector of the Shipping Industry. Transport Economics, 14, 71-84.

[90] Gilman, S. (1999) The Size Economies and Network Efficiency of Large Containerships. Maritime Economics, 1, 39-59. https://doi.org/10.1057/ijme.1999.4 
[91] Heaver, T.D. (2002) The Evolving Roles of Shipping Lines in International Logistics. Maritime Economics, 4, 310-330.

[92] Brewer, A.M., Button, K.J. and Hensher, D.A. (2001) Handbook of Logistics and Supply-Chain Management. Oxford Pergamon Press, Oxford.

[93] Glen, D., Owen, M. and Van Der Meer, R. (1981) Spot and Time Charter Rates for Tankers, 1970-1977. Transport Economics \& Policy, 15, 45-58.

[94] Wright, H. (2000) Spot and Period Rates in the Wet Bulk Shipping Market: Testing for Long-Run Parity. Transport Economics \& Policy, 34, 55-68.

[95] Gardner, B. (1985) The Container Revolution and Its Effects on the Structure of Traditional UK Liner Shipping Companies. Maritime Policy \& Management, 12, 195-208. https://doi.org/10.1080/03088838500000026

[96] Brooks, M.R. and Button, K.J. (1996) The Determinants of Shipping Rates: A North Atlantic Case Study. Transport Logistics, 1, 21-30. https://doi.org/10.1163/156857096300150527

[97] Devanney, J.W., Livanos, V.M. and Stewart, R.J. (1975) Conference Rate Making and the West Coast of South America. Transport Economics \& Policy, 9, 154-177.

[98] Park, R.-K. and De, P. (2004) An Alternative Approach to Efficiency Measurement of Seaports. Maritime economics \& Logistics, 6, 53-69. https://doi.org/10.1057/palgrave.mel.9100094

[99] Butz, D.A. (1993) Ocean Shipping Economics: Free Trade and Antitrust Implications. Contemporary Policy Issues, 11, 86-87. https://doi.org/10.1111/j.1465-7287.1993.tb00393.x

[100] Coeck, C., Notteboom, T.E., Verbeke, A. and Winkelmans, W. (1995) The Unreliability of Maritime Trade Statistics, an Extension of Results. Transport Economics, 22, 217-224.

[101] Bode, S., Isensee, J., Krause, K. and Michaelowa, A. (2002) Climate Policy: Analysis of Ecological, Technical and Economic Implications for International Maritime Transport. Maritime Economics, 4, 164-184. https://doi.org/10.1057/palgrave.ijme.9100038

[102] Vergottis, A. (1988) An Econometric Model of World Shipping. PhD Thesis, City University Business School, London.

[103] Strandenes, S.P. (1984) Price Determination in the Time Charter and Second Hand Markets. WP 6, Norwegian School of Economics and Business Administration.

[104] Granger, C.W.J. and Newbold, P. (1974) Spurious Regressions in Econometrics. Econometrics, 2, 111-120. https://doi.org/10.1016/0304-4076(74)90034-7

[105] Stopford, M. (1997) Maritime Economics. Unwin, London. https://doi.org/10.4324/9780203442661

[106] Goulielmos, A.M. (2010) What Can We Learn from 259 Years of Shipping Cycles? Shipping \& Transport Logistics, 2, 125-150. https://doi.org/10.1504/IJSTL.2010.030863

[107] Goulielmos, A.M. (2013) An Econometric Analysis of the Impact of Vessel Size on Weekly Time Charters: A Study in Volatility (Panamax and Cape). Transport Economics, 40, 31-48. 


\section{Appendix}

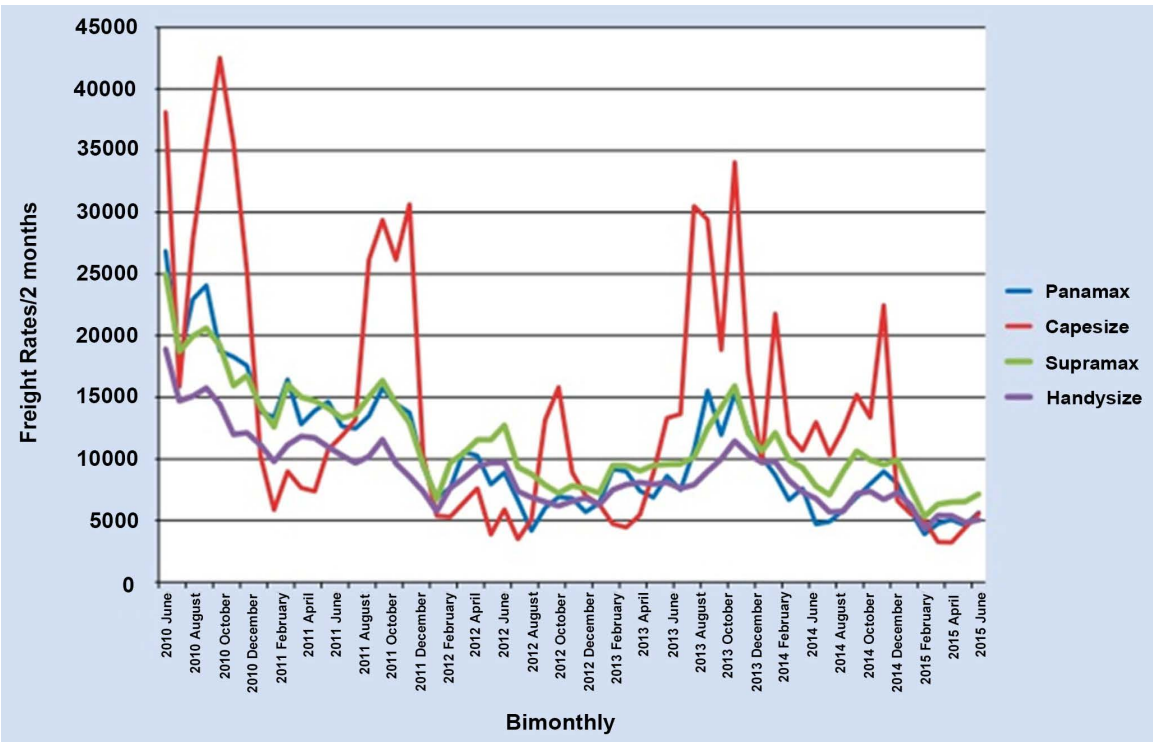

Figure A1. Freight rates for the 4 main types of dry ships, June 2010-June 2015. Source: Clarkson's.

As shown, the red line-belonging to Capesizes-has the higher peaks and thus the higher profitability. From this we get the conclusion that "size risk"-if any-is compensated by higher profitability. Capesizes are the larger ships among those shown more than double than the next Panamax. These served China's trade. There was the old proverb: "big ships, big troubles"; but here (2010-2015) this is not valid. 